\title{
CONSUMER SALES LAW FROM AN ECONOMIC PERSPECTIVE
}

\author{
Roger Van den Bergh and Louis Visscher \\ Rotterdam Institute of Law and Economics, Erasmus University Rotterdam
}

\section{A. Introduction}

In the European internal market consumers have a wide choice of products that become increasingly available through cross-border shopping. Sometimes sellers frustrate consumers' contractual expectations by delivering goods that are not of satisfactory quality. To guarantee a minimum level of consumer protection, EC Directive 1999/44 requires that goods must be in conformity with the contract of sale. ${ }^{1}$ This rule applies regardless of whether the seller behaved negligently. In cases of non conformity consumers have a choice of different remedies for breach of contract by the seller, such as repair or replacement or price reduction. The Directive has been presented as a significant step towards creating an internal consumer market, which would be impeded by fragmented and heterogeneous consumer protection rules. It may be followed in the future by further harmonization initiatives in the field of consumer sales law.

From an economic perspective, two sets of questions arise. First, it may be asked whether legal intervention is necessary to guarantee quality in markets for consumer goods. The standard economic answer to this question is that legal rules may cure market failures, in particular problems of asymmetric information. However, any legal intervention must be justified by a benefit-cost analysis to enhance economic efficiency and avoid counterproductive effects. Consumer protection should be increased only up to the point where its marginal cost equals its marginal benefit. Moreover, market failures should not be replaced by government failures, which lead to outcomes that are worse than those of imperfect markets. Second, Law and Economics scholars have critically analyzed the question relating to the best level of government for designing regulatory responses to market failures. Should rules of consumer protection be enacted at the European level or should regulatory action be taken by the Member States? The economic analysis of federalism and regulatory competition provides several useful insights that are also relevant for discussing the desirability of harmonization of consumer sales law to further market integration.

The structure of this paper is as follows. Section B addresses the question to what extent the market mechanism itself may cure problems of quality deterioration in markets for consumer goods. Particular attention is devoted to the economic function of warranties that are an important means to overcome information asymmetry, affect manufacturers' incentives to increase quality and provide insurance coverage to consumers. Section C analyzes the main provisions of EC Directive 1999/44: the rule on non conformity, the

\footnotetext{
${ }^{1}$ Directive 1999/44/EC of the European Parliament and of the Council of 25 May 1999 on certain aspects of the sale of consumer goods and associated guarantees, OJ L 171, 7.7.1999, p. 12-16.
} 
remedies available to the consumer, and the allocation of liability in the contractual chain (from manufacturer to importer/wholesaler and retailer). In this section, attention is also paid to the implementation of the Directive by the Member States. Even though a full discussion of national laws is outside the scope of this paper, some illustrations will prove to be very useful for a better understanding of the economic analysis. Section D questions the desirability of harmonization of consumer sales law. It offers an overview of the benefits and costs of either harmonization or competition between legal rules and applies these insights to EC Directive 1999/44. Section E concludes.

\section{B. Quality deterioration and the market mechanism}

Below we first provide an overview of the main insights from the economic analysis of consumer protection. This will allow us to understand the reasons of quality deterioration in markets for consumer goods and will explain why goods do not always meet consumers' expectations. Thereafter, we pay particular attention to the role of warranties. This part of the paper will provide insights that are crucial for a proper understanding of the relation between the economic functions of warranties and the rule on non conformity, to be further discussed in Section C.

I. Why consumer markets may fail in providing optimal quality

In his seminal article The Market for Lemons, Nobel Prize laureate George Akerlof shows that quality uncertainty may cause a process of 'adverse selection' through which good quality products are driven out of the market by bad quality products. ${ }^{2}$ Akerlof has considered formally a market where information is imperfect. The seriousness of the information problems depends on both the nature of the goods and the personal qualifications of the buyers (professional buyers or consumers). A useful distinction can be made between search qualities, experience qualities and credence qualities. ${ }^{3}$ If goods have search qualities, consumers may be informed by inspection prior to the purchase; examples include fresh fruit and vegetables and also (the colour of) textiles. In other cases consumers can only learn about quality after purchase. Goods having experience qualities include, among others, houses, cars and stereo equipment. When experience goods are bought, quality uncertainty may be reduced through the 'repeat purchase mechanism'. The use of the goods may provide the necessary information about quality enabling the consumer to decide whether (s)he will make a repeat purchase or not. For some products and services, consumers will not be able to assess quality even after purchase. In such cases quality uncertainty is replaced by 'trust'. Goods or services that possess credence qualities, such as complex medical services but also repair services for durable consumer goods, are bought whenever buyers are sufficiently confident about the professional qualifications of the supplier.

\footnotetext{
${ }^{2}$ G. A. Akerlof, 'The Market for Lemons: Qualitative Uncertainty and the Market Mechanism', (84) Quarterly Journal of Economics 1970, p. 488-500.

${ }^{3}$ P. Nelson, 'Information and Consumer Behavior', (78) Journal of Political Economy 1970, p. 311-329; M. Darby and E. Karni, 'Free Competition and the Optimal Amount of Fraud, (16) Journal of Law and Economics 1973, p. 67-88.
} 
If consumers are not fully informed, two problems arise. First, in the short run inefficient contracts will be concluded. Consumers may also buy goods if the purchase price is higher than the utility they derive from those goods; transfers of goods will not be Pareto optimal. ${ }^{4}$ Second, in the long run bad quality may drive out good quality, as suggested by Akerlof. If consumers cannot distinguish beforehand between good quality and bad quality while sellers can, the maximum price the buyers are willing to pay will be based on average quality. Sellers of good quality face a situation in which the price consumers are willing to pay is below the real value of the product. At this market price sellers may decide not to sell the product and withdraw from the market. If sellers of good quality leave the market, average quality drops and, hence, the price buyers are willing to pay goes down. More sellers of relative good quality will decide to withdraw from the market and, in the end, only the lowest quality will be offered for sale. This process of adverse selection leading to a general lowering of quality is the consequence of a market failure: uninformed buyers are confronted with informed sellers (asymmetric information). The example of the second-hand car market (a 'lemon' is a second hand car of inferior quality) offers a nice illustration of this theoretical argument. In the absence of remedies, information failures may cause a breakdown of this market.

Substantial information asymmetries between manufactures and traders on the one hand and consumers on the other provide the most important economic rationale for consumer protection policies when market-based solutions are unlikely to emerge. Legal intervention may be one of two types: default rules or mandatory regulation. Default rules may fill in gaps if parties did not draft a fully specified contract, which allocates the risk of all possible contingencies. Transaction costs of writing fully specified contracts are prohibitively high. Hence, default rules can save on transaction costs and improve efficiency by providing an allocation of risks which the parties would have preferred in a world of zero transaction costs where contract negotiation is entirely costless. ${ }^{5}$ Regulation, putting freely negotiated contracts aside, reaches much further and should be used only if a number of strict conditions is met. ${ }^{6}$ The benefits to the consumers, in the form of improved quality, must outweigh the administrative and compliance costs of the regulations. This benefit-cost criterion is based on the concept of Kaldor-Hicks efficiency. ${ }^{7}$ According to this criterion, legal changes should be introduced if the gains they bring to the winners are so large that they could potentially compensate the losers. In Europe, full-fledged benefit-cost analyses of consumer regulations are seldom conducted. In the absence of empirical studies costs tend to be chronically underestimated. This is partly because consumer laws have been developed piecemeal. As a result, the incremental cost of each new initiative has seemed minor when looked at individually, even though the totality of the regulatory impact may be enormous.

\footnotetext{
${ }^{4}$ On the concept of Pareto-optimality, see among others H.-B. Schäfer and C. Ott, The Economic Analysis of Civil Law, Cheltenham: Edward Elgar 2004, p. 22; R.D. Cooter and T.S. Ulen, Law \& Economics, $5^{\text {th }}$ Edition, Boston: Pearson Addison Wesley 2008, p. 17.

${ }^{5}$ Schäfer and Ott 2004, p. 299; Cooter and Ulen 2008, p. 217 ff.

${ }^{6}$ A.I. Ogus, Regulation. Legal Form and Economic Theory, Oxford: Clarendon Press 1994, p. 28.

${ }^{7}$ On this concept, see Schäfer and Ott 2004, p. 28 ff; Cooter and Ulen 2008, p. 47.
} 
The market itself offers a number of remedies that may overcome the adverse selection problem: brands, advertising, reputation and warranties. For a proper understanding of the economic effects of EC Directive 1999/44 the role of warranties is crucial; it will be discussed extensively below. Here, some general remarks about other market mechanisms are provided. Brand names are a method sellers use to implicitly guarantee superior quality, because product quality must remain sufficiently high to attract repeat purchases. ${ }^{8}$ Producers having large investments in a brand name will not want to lose the goodwill attached to it. The same reasoning applies to advertising: heavy investments in advertising only pay back if the seller can rely on profits resulting from repeat purchases by satisfied consumers. In cases where there is a danger of opportunistic behaviour (i.e. sellers trying to achieve high profits by selling low quality products), efficiency concerns require that consumers' confidence is protected if information costs are reduced and a confidence premium is paid to the sellers. ${ }^{9}$ Rational consumers may be assumed to be willing to pay higher prices if, by doing so, they can save on information costs. An optimal confidence premium exactly equals the savings from the reduction of information costs. Advertising reduces the search costs of consumers and the costs of advertising campaigns are passed on to consumers via higher resale prices, enabling the sellers to earn a confidence premium. Even if advertisements are seen as merely persuasive, the informative value of advertising does not automatically fall to zero. Under some circumstances the amount of persuasive advertising may be a signal of quality. ${ }^{10}$ Highquality firms selling experience goods will earn high confidence premiums; as a consequence they have a greater incentive to advertise than low-quality firms do. If sellers truthfully disclose high quality and keep quality constant, they will be able to earn high confidence premiums.

Besides brands and advertising, goodwill may be acquired by building a reputation. Firms may gain a clientele that is prepared to pay high prices. The confidence premiums can be used to guarantee quality and finance the costs of legal protection of buyers. However, the reputation mechanism only works if a number of conditions are satisfied. First, there must be repeated interactions between sellers and buyers. Second, buyers must be able to learn from product use about the product's quality. Third, the seller must have sunk an important amount of specific capital in his or her business. These conditions will be more easily satisfied in business-to-business relations than in business-to-consumer contracts. A classic example of where the conditions for building reputation are not satisfied is the market for second-hand cars. Consumers do not buy regularly from the same seller, there is no information exchange on the risks of sold products and there is very little specific

\footnotetext{
${ }^{8}$ B. Klein and K. Leffler, 'The Role of Market Forces in Assuring Contractual Performance', (21) Journal of Political Economy 1981, p. 615-641.

${ }^{9}$ Schäfer and Ott 2004, p. 377-381

${ }^{10}$ P. Milgrom and J. Roberts, 'Price and Advertising Signals of Product Quality', (26) Journal of Political Economy 1986, p. 796-821.
} 
capital invested. ${ }^{11}$ Consequently, the reputation mechanism does not work and fly-bynight firms may enter to market to reap high premiums for opportunistic behaviour.

Commercial guarantees or warranties ${ }^{12}$ are promises made by manufacturers or sellers to assume specific responsibilities in case the quality or performance of goods do not conform to the contractual expectations of buyers. There is a large body of Law and Economics literature on warranties. ${ }^{13}$ Authors agree that warranties have three main economic functions: i) they contribute to risk spreading (insurance function); ii) they improve information flows in consumer markets (information revealing function or signaling function), and iii) they provide incentives to perform the contract (incentive function). ${ }^{14}$ Theoretically warranties may cover the entire life of products (full warranty) but in practice commercial warranties are limited in time and scope (partial warranties). Given the different economic functions, the 'optimal' warranty will vary according to the risk attitudes of sellers and buyers, the availability of information in markets and the possibility of either sellers and/or buyers to control the risk of non conformity. A full warranty will be efficient only under very restrictive conditions; partial warranties will be preferable in the vast majority of cases. ${ }^{15}$

The first economic function of a warranty is to provide insurance when the risk that the product is unsatisfactory is exogenous. This implies that neither the seller nor the buyer may control the risk of non conformity. If the warranty is an instrument for providing insurance, the seller should offer a full warranty if (s)he is the superior risk-bearer. Conversely, no warranty should be offered if the buyer is better able to bear the risk. In the economic terminology, a full warranty is efficient if the seller is risk-neutral and the consumer is risk-averse whereas no warranty should be offered if the seller is risk-averse and the buyer is risk-neutral. ${ }^{16} \mathrm{~A}$ risk-averse buyer is prepared to pay an insurance

${ }^{11}$ Schäfer and Ott 2004, p 348.

${ }^{12}$ In this paper, the terms guarantees and warranties are used interchangeably.

${ }^{13}$ G.L. Priest, 'A Theory of the Consumer Product Warranty', (90) Yale Law Journal 1981, p. 1297-1352; K. Wehrt, 'Warranties', in: B. Bouckaert and G. De Geest (eds), Encyclopedia of Law and Economics, Volume III. The Regulation of Contracts, Cheltenham: Edward Elgar 2000, p. 179-199; F. Parisi, 'The Harmonization of Legal Warranties in European Sales Law: an Economic Analysis', (52) The American Journal of Comparative Law 2004, p. 403-432; Schäfer and Ott 2004, p. 336-354.

${ }^{14}$ It is interesting to note that the insurance function and the signaling function are recognized also in psycholy, even though they appear under different names. See the contribution by D. Standop and G. Grunwald (section B.I) in this Volume. The analysis of the incentive function thus appears to be the main added value of economic analysis of law.

${ }_{16}^{15}$ Parisi 2004, p. $407 \mathrm{ff}$.

${ }^{16}$ A risk-neutral actor is only concerned with the expected value of a certain project and not with the possible magnitude of the outcome. (S)he therefore is indifferent between a project with a certain outcome of $€ 100$ and a project with a $50 \%$ probability of $€ 200$. A risk-averse actor on the other hand is also concerned with the possible magnitude of the outcome and prefers the certainty of $€ 100$ over the $50 \%$ possibility of $€ 200$. This risk attitude is caused by the decreasing marginal utility of wealth. This concept entails that the utility-value of changes in wealth depends on the wealth level of the actor involved. For example, $€ 100$ is worth a lot to a poor person, because (s)he can use it to satisfy important needs such as food and clothing. The same $€ 100$ is worth less to a rich person, because (s)he will use it to satisfy less important needs (more important needs are already satisfied). Hence, the higher one's initial wealth level, the smaller the change in utility of receiving (or losing) a certain amount. This also implies that for a single person, losing a twice as large amount of wealth leads to a more than twice as large decrease in utility, 
premium to guarantee the quality of the product that is higher than the expected value of the loss. For example, if the expected loss amounts to $€ 10$, a risk-averse buyer is willing to pay more than $€ 100$ instead of getting the product without a warranty but a reduced price of $€ 90$. If the seller is risk-neutral, - i.e. (s)he is indifferent between selling the product at 90 without warranty or at 100 with warranty - , a warranty is the most efficient way of insuring risk-averse buyers. ${ }^{17}$ The reason is that alternative third-party insurance would be too costly and lead to moral hazard ${ }^{18}$ on the part of the seller. It follows from the foregoing that warranties play no role if both seller and buyer are risk-neutral since in this scenario there is no need to reallocate risks. Even though it is safe to assume that sellers are generally risk-neutral, in some cases also sellers will not be completely indifferent towards risk and full warranties will then be inefficient. In the last scenario optimal warranties should be partial and reflect the different degrees of risk aversion of both sellers and buyers. ${ }^{19}$

The second economic function of a warranty is to reveal information; it can be characterized also as a signaling function. The optimal warranty will differ according to the distribution of information in markets. Below, four hypotheses are distinguished. ${ }^{20}$

i) If the seller possesses private information and the buyer has no such information, the above mentioned 'market for lemons' problem will materialize. If buyers cannot distinguish low quality from high quality products, they will not be willing to pay a price that is higher than the value of average quality and a process of adverse selection will start developing. The ensuing quality deterioration can be stopped if sellers offer full warranties. The price of this warranty will at least equal the expected cost of future claims for non performance. Warranties will be expensive for low quality products but cheaper for high quality products. If the price of the warranty is indicated separately from the price of the product itself, buyers will be able to infer the actual type of seller from the observation of the warranty offered. Also, the quality signal may be too expensive for sellers of low-quality goods, since they would become more costly than high-quality goods. In the terminology of game theory, a separating equilibrium will occur. ${ }^{21}$ In this

because the larger loss goes at the expense of more important needs. Analogously, receiving a twice as large amount of wealth leads to a less than twice as large increase in utility. This results in the outcome that risk-averse actors prefer a higher probability of losing/winning a smaller amount over a smaller probability of losing/winning a larger amount, where the expected value of the more uncertain project can even be lower than that of the more certain project. Insurances transform small probabilities of large losses (the insured events) into the certainty of a small loss (payment of the premium). Risk-averse actors are willing to pay a premium which is higher than the expected loss of the insured event.

17 Schäfer and Ott 2004, p. 338-339.

18 This risk materializes because the seller will have no incentive to minimize the probability of selling defective products. The concept of moral hazard means that an insured party may change its behaviour after the insurance contract is closed. After all, in case the insured event materializes, the insured party is indemnified by the insurance. (S)he therefore does not receive incentives to avoid the insured event from occurring, unless the insurer is able to monitor his or her behaviour and can adapt the premium accordingly. Alternatively, contractual arrangements such as deductibles, bonus/malus discounts or coverage exclusions can be used to provide behavioural incentives to the insured.

${ }^{19}$ Parisi 2004, p. 409.

${ }^{20}$ Our analysis follows Parisi 2004, p. $410 \mathrm{ff}$.

${ }^{21}$ Schäfer and Ott 2004, p. 341. In a separating equilibrium, different types of players send out different signals, so that the other players can draw the correct inferences from the observed signal. In the context of our paper, sellers of high quality goods and sellers of low quality goods cannot be distinguished by means 
way, the information asymmetry of buyers preferring high quality-high price products is cured and the process of adverse selection is stopped.

ii) In the converse hypothesis, where the buyer possesses private information (e.g. on the use of the product) whereas the seller has no such information, an optimal outcome will be achieved if products are sold without a warranty. The intensity of use varies significantly across buyers, as a comparison of private use (car used by a family) and commercial or industrial use (car used by a taxi company) may illustrate. Sellers cannot always distinguish high loss buyers from low loss buyers but the latter will make themselves known by buying products without warranty at a discounted price.

iii) In the absence of information asymmetries in markets, warranties have no information revealing function.

iv) Finally, in many real-life cases both sellers and buyers have private information and, therefore, partial warranties will be optimal. Sellers are aware of the percentage of goods that will likely become defective after some use and buyers have private information on the future use of the good. In equilibrium, high defect rate sellers will serve buyers with small individual losses and low defect rate sellers will sell to buyers who expect large losses. $^{22}$

The third economic function of a warranty relates to contract performance. In as far a warranty fulfils an insurance function, the risk is exogenous and warranties do not play a role in providing incentives to supply goods that are of satisfactory quality. The picture changes in case of endogenous risks, so that the seller and/or the buyer control(s) the risk of product failure. If the seller controls the risk of non conformity, (s)he is the 'cheapest risk avoider' and a full warranty will be efficient. The warranty improves product quality, since it may pay the seller to invest in lowering the risk of having to take care of repair or replacement or pay damages. The seller will have an incentive to invest in additional quality measures as long as the marginal benefit of those measures (improved product quality and increased consumer satisfaction) exceeds the marginal cost in terms of remedies claimed by the buyer. By contrast, if the buyer controls the risk, no warranty should be offered. If both seller and buyer control the risk of non conformity, a partial warranty will be efficient.

of the product itself, because the buyer cannot differentiate between the two types of goods. However, if the sellers know the quality of their product, they can signal the quality by the terms of the warranty. A separating equilibrium can occur only if the costs of sending the high quality signal are much higher for low quality sellers, so that it is too expensive for the latter to send such a signal. In this case, high quality sellers will offer the (cheap) high quality warranty, whereas low quality sellers will offer the (expensive) low quality warranty. If the cost difference between the two types of signals is not large enough, low quality sellers are able to send the same signal as high quality signals, so that the buyer cannot distinguish between the two types. This is called a pooling equilibrium. See e.g. A. Dixit and S. Skeath, Games of Strategy, $2^{\text {nd }}$ Edition, New York: W.W. Norton \& Company 2004, p. 284, 285. To summarize: in a separating equilibrium the different types of players behave differently, but in a pooling equilibrium they behave the same, see J. Watson, Strategy: An Introduction to Game Theory, New York: W.W. Norton \& Company 2002, p. 276, 277.

${ }^{22}$ Parisi 2004, p. 412. 


\section{Economic analysis of EC Directive 99/44 and its implementation in some Member States}

\section{The conformity requirement}

The seller is liable to the consumer for the conformity of the goods with the contract of sale. According to Article 2 of the Directive, consumer goods are presumed to be in conformity with the contract if they: i) comply with the description given by the seller, ii) are fit for any particular purpose for which the consumer requires them and which is made known to the seller, iii) are fit for the purposes for which goods of the same type are normally used, and iv) show the quality and performance, which are normal in goods of the same type and which the consumer can reasonably expect, also taking into account statements in advertising or on labeling.

\section{Does the conformity requirement equal a statutory warranty?}

There exist different views in the literature regarding the qualification of the conformity requirement as a mandatory legal warranty. In the economic and marketing literature, a very broad definition of a warranty is used: it encompasses all legally enforceable claims by the buyer against the seller if the purchased product does not meet the buyers' expectations. ${ }^{23}$ Within this broad definition, the rule on non conformity can be seen as a legally required warranty. Lawyers may object to this qualification since legal systems usually distinguish the buyers' rights that are based on legislation from promises given by the seller to assume specific responsibilities in case of defective or unsuitable products. In case the buyer wants to invoke the warranty, (s)he is relieved from proving that the defect was present at the time of the sale and the passing of the risk. From a strictly legal perspective, it may be argued that the (objectionable) qualification of the conformity requirement as a mandatory legal warranty is caused by the combination of a duty to deliver goods of satisfactory quality and the limitation periods, which make the exercise of consumers' rights subject to time limits that are typical of warranties offered by sellers of consumer goods. It should be added that the Directive itself also distinguishes the conformity requirement (Articles 2-3) and guarantees offered by sellers (Article 6). With respect to the latter, the regulation is kept to a minimum. Commercial guarantees may not affect the consumer's rights under national law and must provide intelligible information on the scope of the warranty, its duration, and the conditions for making claims. Article 6 of the Directive does not regulate the scope of coverage of the guarantee or the remedies offered to consumers. Consequently, it enables producers and retailers to offer different commercial warranties that provide full or partial coverage and diverging remedies. In sum, a legal distinction can be made between the duty to deliver goods that are in conformity with the contract of sale and commercial guarantees. However, as will be further explained below, the rule on non conformity generates economic effects that are similar to legal rights provided by warranties. This causes a number of problems from a perspective of economic efficiency.

\footnotetext{
${ }^{23}$ Parisi 2004, p. 407; Schäfer and Ott 2004, p. 338. See also the contribution by D. Standop and G. Grunwald (section A) in this Volume.
} 
It seems clear that the European legislator did not have the economic functions of warranties in mind when the text of the Directive was drafted. The three main goals of warranties require different levels of protection. Parties may be better informed than a regulator about the risk and they may negotiate a warranty coverage and remedies that optimally suit their preferences. The legislator could reduce the transaction costs of negotiating by setting default rules but should remain extremely reluctant to impose mandatory rules that may inhibit the development of optimal warranties through the market mechanism. If one tries to find an implicit economic logic, the Directive's formulation focuses mainly on the incentive function of warranties. In his or her capacity as the cheapest risk avoider, the seller is given an incentive to deliver goods of sufficient quality in order to avoid the imposition of one of the remedies given to the buyer. One may also deduce an insurance function from the strict liability rule contained in Article 3 (1) in fine. The liability for non conformity includes risks that existed at the time of delivery and could not be controlled for by the seller. However, liability for risks due to exogenous events that happened after the delivery of the product is excluded, so that the conformity requirement does not provide full insurance coverage. The difference between a legal and an economic approach becomes most clear if the signaling function of warranties is taken into account. The EC Directive missed the opportunity to improve market transparency. Sellers should have been forced to separately indicate the product price and the price for the warranty. ${ }^{24}$ The full product price includes the costs of production, the costs of expected claims for non conformity and the profit margin of the seller. The price of the warranty reflects the scope of the insurance coverage offered as well as the costs of warranty claims exceeding the legal duties under the conformity requirement. Unfortunately on this point the Directive is fully deprived of economic logic since a guarantee is defined as obligations "given without extra charge", to reimburse the price paid or to replace, repair consumer goods if they do not meet the specifications set out in the guarantee statement (Article 1,2e). This definition neglects the basic economic insight that the price of warranties varies according to the scope of their coverage and that revealing these prices improves market transparency.

The discussion about whether the Directive has imposed a statutory warranty would be futile if the market could correct a potential misallocation of legal rights. According to the Coase theorem ${ }^{25}$, sellers and consumers will negotiate a solution that maximizes their joint benefits. If the statutory warranty has too long a duration and is too expensive, the legal assignment of rights only provides a start point from where the scope of coverage and the duration of the protection can be corrected. The same negotiation process may rectify warranties granting legal protection which is too limited in scope or time. Unfortunately, the Directive imposes mandatory rules. Parties may not waive the rights

\footnotetext{
${ }^{24}$ A. Renda, 'Annotazioni in merito alla imminente direttiva sulle garanzie contrattuali: un' occasione mancata?', Diritto dei consumi/Consumer law, 1997, p. 605-606. See also Parisi 2004, p. 415.

${ }^{25}$ R.H. Coase, 'The Problem of Social Cost', (3) Journal of Law and Economics 1960, p. 1-44. According to Coase, absent transaction costs, entitlements will ultimately be allocated to the party valuing them the highest, irrespective of the initial distribution, so that the joint welfare of the parties involved is maximized. In case an entitlement is granted to a party who does not value it the highest, with the use of costless negotiations this entitlement will be transferred to someone who values it higher. For these negotiations to be feasible, it is required that the initial distribution of entitlements is clear, because this forms the basis of the negotiations.
} 
granted to consumers (Article 7); this impedes downward adjustments of warranty-like duties. The limitation periods imposed by the Directive are two years for new products and one year for second-hand goods. The effect of these requirements is that sellers are no longer able to offer commercial guarantees for product defects covering shorter periods. Commercial warranties may extend the scope of the legal rights granted to the consumer, by not requiring proof that the product was defect at the time of delivery or offering a longer period of protection. Conversely, commercial warranties may not reduce the protection given to the consumer by reducing the limitation period within which the consumer may claim one of the remedies granted by the Directive. If lack of conformity becomes apparent within six months of delivery of the goods, it is presumed to have existed at the time of delivery (Article 5,3) and the seller cannot exclude his liability by means of a contractual warranty (Article 7).

Mandatory levels of warranties may be inefficient if consumers have heterogeneous preferences. A consumer who temporarily resides in an EC Member State may be interested to buy a second-hand car that (s)he will use during a six month stay (instead of renting a new car for the same period). This consumer will not be interested in a warranty for a one year period. The latter will be more attractive to a regular resident of that Member State, who would eventually even prefer a commercial warranty for a longer period. Mandatory rules do not allow satisfying these diverging preferences. Competitive markets may develop commercial warranties that are more in line with consumers' preferences. Uniform rules may decrease transaction costs if they reflect the preferences of the majority of contract parties. However, to avoid inefficiencies it is crucial that these uniform rules are not mandatory. In the opposite case, consumer choices may be reduced and consumer protection may become counterproductive. Schäfer and Ott report that the number of second-hand cars exported from Germany to non-EU countries has increased spectacularly from 10.00 per month in 1999 to 60.000 in 2002. In this way, less wealthy consumers are no longer able to buy a cheap used car from a professional seller. ${ }^{26}$ One does not escape from the question: Who protects consumers from consumer protection? ${ }^{27}$

\section{The duration of limitation periods}

The limitation periods imposed by the Directive are two years for new products and one year for second-hand goods. An economic evaluation of limitation periods entails a weighing of their costs and benefits. Ogus analyzes limitation periods which relate to the right of bringing a claim. This is a somewhat different topic from the limitation periods in the Directive, but the arguments provided by Ogus are instructive. On the cost side he distinguishes four elements. ${ }^{28}$ First, claimants who do not bring their claim within the limitation period lose the value of the remedy. Second, defendants do not get optimal

\footnotetext{
${ }^{26}$ Schäfer and Ott 2004, p. 352.

27 See generally R. Van den Bergh, 'Wer schützt die europäischen Verbraucher vor dem Brüsseler Verbraucherschutz? Zu den möglichen adversen Effekten der europäischen Richtlinien zum Schutze des Verbrauchers', in: C. Ott and H.-B. Schäfer (eds), Effiziente Verhaltenssteuerung und Kooperation im Zivilrecht, Tübingen: Mohr Siebeck 1997, p. 77-102.

28 A.I. Ogus, 'Limitations of Actions: Justified or Unjustified Complexities?', paper presented at the Amsterdam Centre for Law and Economics Seminar on December 12, 2005, p. 5, 6. <www.cms.uva.nl/acle/object.cfm/objectid=05074599-2043-4292-8B8E6A159F5A45BD>
} 
incentives for efficient behaviour because some of the possible claims will not be made within the limitation period. Third, the shorter the limitation period the more the claimant with a difficult claim will have to invest in obtaining the necessary evidence in time. Otherwise, (s)he will have to bring the claim without this investment and run the risk of failing the claim. This type of costs seems less relevant for the topic of non conformity discussed in this paper. Fourth, defendants may engage in opportunistic behavior thus trying to induce a delay on the side of claimants. Ogus also distinguishes four categories of benefits. First, litigation costs are reduced because some claims will not be made in time. Second, the costs caused by uncertainty whether or not a claim will be made decrease. Third, the costs of storing information that could be used in case a trial would follow decrease. Fourth, the error costs of wrong decisions caused by the deterioration of information over time are reduced. The latter two types of costs are less relevant for the topic of non conformity.

The optimal limitation period is determined by a weighing of the costs and benefits they entail. In as far as the contract parties involved are best able to assess the costs and benefits that are relevant in their situation, they should be allowed to decide which limitation period suits their needs best. However, if such an agreed upon limitation period causes externalities, public intervention might be warranted. Parisi holds that, if sellers provide default warranties instead of negotiating them in every individual case, their duration will roughly correspond to the average time period that is likely requested by consumers. The optimal choice is the one that minimizes the sum of the transaction costs of renegotiation of separate warranty arrangements. ${ }^{29}$ Schäfer and Ott argue that short limitation periods on movables are problematic because often defects only emerge after a certain amount of time has elapsed. The shorter the limitation period, the larger the chance that the defect only emerges after the period has already expired. This would increase the costs as distinguished by Ogus. In determining the optimal limitation period, Schäfer and Ott spend attention to several factors. ${ }^{30}$ First, the more dynamic the development of a product the shorter the optimal limitation period will be. After all, consumers are not willing to pay for a long limitation period if they will replace the product within this period. Second, the longer the average lifespan of the product the longer the optimal limitation period will be. Third, the larger the scope for possible seller moral hazard the longer the optimal limitation period should be, in order to combat the incentive to produce goods that break down after the limitation period has expired. Fourth, the opposite holds for consumer moral hazard where buyer's behaviour is difficult to monitor. Fifth, the more valuable the product the longer the optimal limitation period will be. After all, the concept of decreasing marginal utility of wealth implies that with increasing losses the actor is willing to pay a higher insurance premium.

In sum, the Law and Economics literature suggests that the optimal limitation period depends on many factors. The standard two year period for new products and one year period for second-hand goods does not allow this fine-tuning. Many cases are conceivable where rational, well-informed parties would like to agree on a shorter period, for example cell-phones. The technological developments succeed each other at a very

\footnotetext{
${ }^{29}$ Parisi 2004, p. 415.

${ }^{30}$ Schäfer and Ott 2004, p. 350, 351.
} 
high pace, so that the 'economic life cycle' of such a product is much shorter than two years. No rational consumer would be willing to buy a warranty of two years, given that he will have replaced his cell-phone with a newer type by then. Furthermore, the differences between cell-phones (with or without photo or video camera, mobile internet, Bluetooth, qwerty-keyboard, et cetera) and their respective prices, as well as the intensity of use are so great that the optimal warranty period will also differ. The fixed minimum limitation periods frustrate the possibility to meet the preferences of the different parties involved. ${ }^{31}$ Conversely, in cases where buyers underestimate the expected loss and on the basis of this incomplete information would buy an inefficiently short warranty, longer mandatory limitation periods could serve to correct this problem.

\section{Further comments}

In spite of the undesirable 'mandatory warranty effects' of the conformity requirement and the inefficiencies caused by non-optimal limitation periods, some specific rules of the EC Directive show an implicit economic logic. Two examples may be given. First, consumer goods are presumed to be in conformity with the contract if they are fit for any particular purpose for which the consumer requires them and which (s)he made known to the seller (Article 2,2,b). This rule gives incentives to the seller to ask information from the buyer on the future use of the product (specific needs, in which environment, intensity) or to the buyer to convey this information. In section B.2 we already indicated that inefficient outcomes result if sellers cannot distinguish high loss buyers from low loss buyers. By receiving information about the purpose of the product use, this information asymmetry is overcome and the coverage of the 'statutory warranty' may be set at an optimal level. The seller can decide not to deliver the good if it is not fit for the use envisaged by the consumer and may thus escape liability for non conformity. Second, there shall be deemed not to be a lack of conformity if the consumer was aware, or could not reasonably be unaware, of the lack of conformity (Article 2,3). This rule provides incentives to consumers to take efficient care when buying goods. If the consumer is the 'cheapest risk avoider' warranty protection should be excluded (see section B.2).

More problematic is the presumption holding that consumer goods are in conformity with the contract if they show the quality and performance which the consumer can reasonably expect "taking into account any public statements on the specific characteristics of the goods made about them by the seller, the producer or his representative, particularly in advertising or on labeling' (Article 2, 2,d). Prior to the Directive, seller's liability for producer's statements was not a common rule under national laws of the Member States. For example, in Germany courts did not hold sellers liable for producer's information if statements in advertising did not explicitly form part of the sales contract (with one notable, but heavily criticized exception). ${ }^{32}$ By contrast, in England recent case law suggests that the seller's reliance on the skill and judgment of the supplier in identifying goods suitable for a particular purpose, which may be deduced from promotional material for the retail trade, suffices to establish seller's liability. ${ }^{33}$ Under the harmonized rules,

\footnotetext{
${ }^{31}$ Also see Parisi 2004, p. 426.

${ }^{32}$ See the contribution by S. Bittner and P. Rott (section B.I) in this Volume.

${ }^{33}$ See the contribution by C. Twigg-Flesner (section II.1.c) in this Volume.
} 
sellers are liable for statements on the characteristics of the good made in advertising. From an economic perspective, it may be doubted whether sellers should be held liable for information provided to consumers the contents of which they cannot control. Of course, in as far as sellers are able to recoup their liability expenses from the producer, it is ultimately the latter who bears the negative consequences of public statements. However, recoupment is costly and it is not likely that in the end all relevant costs will be borne by the producer. Therefore, the producer may get incentives to issue public statements which increase his or her revenues, while the costs of these statements are borne by others. The seller may respond to this by increasing the price of the product, so that ultimately consumers bear the added costs. Targeting the producer in the first place makes more economic sense, because this provides incentives to the actor who actually controls the contents of the public statements.

\section{Remedies for the consumer}

EC Directive 1999/44 leaves consumers the choice between different remedies: i) repair or replacement, unless this is impossible or disproportionate, ii) price reduction, or iii) rescission of the contract, unless the lack of conformity is minor. There is an extensive economic literature dealing with remedies for breach of contract. ${ }^{34}$ We start this section with an analysis of this literature, since it provides relevant insights for the topic of this paper. Subsequently we analyze the remedies for non conformity, which are chosen by the Directive, from an economic viewpoint and we relate our findings to some of the country reports contained in this volume.

\section{General insights}

The literature on remedies for breach of contract focuses on the question under which conditions either damages or specific performance is the preferred remedy. The starting point of the economic analysis is that parties enter into a contract to benefit from it. The transaction produces a cooperative surplus, which increases the welfare of the parties involved. However, between the time the contract was closed and the time it must be executed, the circumstances might have changed in such a way that the fulfillment of the contractual obligations has become unprofitable. The question then arises if the creditor should be able to force the debtor to perform, or if (s)he should accept damages instead.

\footnotetext{
${ }^{34}$ See e.g. A. Schwartz, 'The Case for Specific Performance', (89) Yale Law Journal 1979, p. 271-306; T.S. Ulen, 'The Efficiency of Specific Performance: Toward a Unified Theory of Contract Remedies', (83) Michigan Law Review 1984, p. 341-403; A.S. Edlin, 'Breach Remedies', in: P. Newman (ed), The New Palgrave Dictionary of Economics and the Law, Londen: MacMillan Reference Limited 1998, p. 174-179; T.S. Ulen, 'Specific Performance', in: P. Newman (ed), The New Palgrave Dictionary of Economics and the Law, London: Macmillan Reference Limited 1998, p. 481-383; P.G. Mahoney, 'Contract Remedies: General', in: B. Bouckaert and G. De Geest (eds), Encyclopedia of Law and Economics, Volume III. The Regulation of Contracts, Cheltenham: Edward Elgar 2000, p. 117-140; S. Shavell, 'Specific Performance Versus Damages for Breach of Contract: An Economic Analysis', (84) Texas Law Review 2006, p. 831876; M.A. Eisenberg, 'Actual and Virtual Specific Performance, the Theory of Efficient Breach, and the Indifference Principle in Contract Law’, (93) California Law Review 2005, p. 975-1050.
} 
The economic answer to the above question is nuanced. In principle, if the cost of performance to the debtor exceeds the benefit to the creditor, damages are the preferred remedy. This is what parties would have agreed upon ex ante if they had covered this contingency in the contract. After all, agreeing that the debtor does not have to perform if his loss exceeds the benefit of the creditor increases the cooperative surplus. Parties can share this larger surplus and both benefit from this arrangement. Conversely, if a debtor is forced to perform under such conditions, (s)he will charge a premium for this obligation. Given that the cost of performing outweighs the benefit to the creditor, this premium will exceed the value that the latter attaches to performance ex ante. Hence, it is economically desirable that a debtor is allowed to breach the contract if the performance cost exceeds the benefit. If the debtor has to pay damages which bring the creditor in the same financial position as he would have reached if the debtor had performed, the debtor will make the correct decision on breaching the contract. 'Expectation damages', which equal the value of performance to the creditor, lead to the ideal outcome of 'efficient breach': the debtor only breaches if the cost of performing outweighs the benefit to the creditor, which maximizes the joint welfare of the contract parties involved.

It must be added that the above line of reasoning holds only if the expectation damages fully compensate the creditor for the loss suffered. In practice, this ideal of full compensation is hardly ever reached. In many transactions, subjective values such as taste and emotions play an important role, so that it is (very) difficult to exactly determine the value of performance to the creditor. These uncertainties often lead to undercompensation. ${ }^{35}$ In addition, the advantages the creditor hopes to get out of the contract may be partly uncertain, for example the profit (s)he hopes to make with using a machine (s)he has bought. In as far as courts are reluctant to compensate an uncertain loss damages will again be under-compensatory. If damages are lower than perfect expectation damages, the debtor may also breach the contract in a situation where the loss of performance is actually lower than the loss of the creditor of non performance, so that social welfare decreases.

The more difficult the correct assessment of damages, the more attractive specific performance becomes. The Law and Economics literature, therefore, agrees that specific performance is the preferred remedy if the contract concerns unique goods, such as objects of art and real estate, because subjective elements dominate when the size of the loss must be determined. In the case of replaceable goods, damages can be calculated by taking the price of a substitute good and are thus better feasible. However, there might still be some under-compensation because the creditor has to invest additional efforts in closing the second contract. The creditor loses time, may be annoyed by the non performance, and so on. These problems do not necessarily lead to a preference for specific performance, because in the latter scenario the unwilling debtor has to be monitored, which is also costly. Schwartz argues that damages should be the default remedy with replaceable goods, but that the creditor should be allowed to choose specific performance instead. This way, if the monitoring costs are high (for example, when the debtor has to perform a service) the creditor will prefer the default remedy. Only in cases where (s)he fears significant under-compensation (s)he will choose specific performance.

${ }^{35}$ Schwartz 1979, p. 276; Ulen 1998, p. 482. 
A last relevant element for determining the choice between remedies for breach of contract is the distinction between production contracts and other contracts. In the case new goods must still be produced, damages are the better remedy. As argued by Shavell, damages avoid inefficient performance in situations where production costs have risen. Conversely, if contracts concern the transfer of existing products specific performance is to be preferred in order to avoid the problems of under-compensation. ${ }^{36}$

\section{Economic analysis of the remedies provided by the Directive}

What can be learnt from the above analysis for the economic assessment of the remedies chosen by the Directive? In our view, the duty to repair resembles specific performance, because the debtor is forced to provide what (s)he should have delivered in the first place: a product which meets the conformity requirement. ${ }^{37}$ In many cases, repair will be a costeffective way to solve the problem of non conformity. However, the costs of repair might be higher than the value it adds or the value of the product in the first place. If the creditor could force the debtor to repair even in such circumstances, the latter would include a premium for this risk in the product price. This risk premium would be higher than the value of repair to the former. The provision that repair is no available remedy if it is disproportionate (or impossible, which economically speaking boils down to prohibitively high costs) therefore makes economic sense. In defining disproportionality, the Directive does not directly compare the seller's costs of repair with the value of repair to the buyer but with the costs of the other available remedies. In this respect, the Directive mentions as relevant factors: the value of the goods if there would have been no lack of conformity, as well as the significance of the lack of conformity. This opens the possibility for a correct weighing of the relevant costs and benefits. Whether an efficient outcome will be reached ultimately depends on the interpretation of the terms of the Directive. The German contribution in this Volume shows that disproportionality is sometimes interpreted as a situation where the costs of repair exceed $150 \%$ of the value of the goods. ${ }^{38}$ The correct economic weighing, however, requires a comparison of the costs of repair to the seller and the increase of value to the buyer. In the Spanish report it can be read that "the costs must be considerably more expensive". 39 Economically speaking, this is also a too strict criterion. According to Parisi, the Directive strikes a sensible balance between the need to protect buyers' legitimate expectations and the need to minimize the performance costs of the sale. ${ }^{40}$ In our view, whether or not the balance is sensible boils down to the interpretation of proportionality in practice.

If repair is not possible or too costly, replacement is presented as an alternative remedy. At this point, we may recall the economic argument that in the case of replaceable goods the creditor can claim from the non performing debtor damages equaling the amount of the price of a substitute good. If the debtor provides the substitute by replacing the

\footnotetext{
${ }^{36}$ Shavell 2006, p. $843 \mathrm{ff}$ and p. $851 \mathrm{ff}$.

${ }^{37}$ Basedow also regards repair (and replacement) as forms of specific performance. See J. Basedow, 'Towards a Universal Doctrine of Breach of Contract: the Impact of the CISG', (25) International Review of Law and Economics 2005, p. 493.

${ }^{38}$ See the contribution by S. Bittner and P. Rott (section B.II.2.a) in this Volume.

${ }^{39}$ See the contribution by S. Navas Navarro (section A.II.3.a) in this Volume.

${ }^{40}$ Parisi 2004, p. 420.
} 
defective product, the same result is reached. Obviously, the creditor should return the product, which did not meet the conformity requirement. Impossibility and disproportionality limit the availability of this remedy, which again makes economic sense. Another important consideration is that the buyer can use the remedy of replacement without first having to go to court, which would be necessary in case of damages (or if the proportionality of the repair costs must be assessed). This characteristic saves on adjudication costs. ${ }^{41}$

In cases where repair or replacement is not available due to impossibility or disproportionality, a price reduction is possible. At this point, the Directive raises two issues. First, does the order (implying that a price reduction can be asked for only if repair or replacement is impossible) make economic sense? Second, how must the remedy of price reduction be assessed economically? Wehrt discusses the ex post effects that different remedies have on the interaction between buyer and seller after the non conformity has become apparent. ${ }^{42}$ His starting point is that subsequent delivery of a faultless product would normally provide the buyer with what (s)he contracted for. If a buyer prefers a price reduction over subsequent delivery, this indicates that (s)he prefers money compensation to getting a faultless product. Hence, the price reduction leads to over-compensation. Wehrt explains this outcome by arguing that the price reduction is based on the loss of an average buyer, so that consumers with lower losses prefer the price reduction. Next, if a buyer prefers rescission over subsequent delivery, this indicates that (s)he regrets the buy and that (s)he uses the non conformity claim as a way to get out of the contract. The rescission remedy should be restricted to situations where the non conformity provides new information about the product in its non-defective state, lowering the initial valuation of the buyer. The option of repair is important to avoid that the buyer can threaten to ask for replacement in situations where repair is much more cost-effective. Hence, the order of remedies, namely that the buyer at a first stage can ask only repair or replacement and that at a second stage price reduction or rescission become available as remedies, makes economic sense from the perspective of ex post incentives. This in its turn has an impact on the ex ante quality incentives. After all, if the buyer could systematically choose the remedy that suits him or her best (overcompensation through price reduction or rescission if he regrets the buy), the seller would get excessive incentives to avoid non conformity and over-deterrence would result.

The second question relates to the (in)efficiency of a price reduction. It remains to be seen if this remedy is powerful enough to provide the producer with the correct incentives to deliver goods in conformity with the contractual obligations. Above, it already became clear that the correct magnitude of damages in case of breach of contract is determined by the value of performance to the creditor (expectation damages). Given that people only buy a product or service if they value it at least as high as its price, a mere price reduction might not be adequate to compensate the buyer for his or her loss. After all, (s)he did not want to buy a cheaper product of lower quality in the first place, but in essence that is

\footnotetext{
${ }^{41}$ Parisi 2004, p. 420.

${ }^{42}$ K. Wehrt, 'Strategic Behaviour, Defective Products and Subsequent Performance', in: B. Bouckaert and G. De Geest (eds), Essays in Law and Economics II: Contract Law, Regulation, and Reflections on Law and Economics, Antwerpen: Maklu 1995, p. 37-39.
} 
what (s)he gets after the price reduction. Torsello rightfully argues that price reduction is not a form of damages. In his view it is even more closely related to specific performance than to damages. ${ }^{43}$ What is relevant for the purpose of our paper, however, is the fact that price reduction is a remedy which consists of the payment of money, whereas repair and replacement require the debtor to live up to the original promises. The characteristic of a money payment makes sure that excessive performance can be avoided. Torsello states that price reduction is an efficient remedy in a situation where the buyer is not substantially deprived of his or her reasonable expectations. It is exactly this last prerequisite which in our view is troublesome. After all, a price reduction might not be able to compensate the buyer for the loss in value due to the non conformity. The Directive opens the possibility of a price reduction if the consumer is entitled to neither repair nor replacement, or if the seller has not offered the remedy within a reasonable time or without significant inconvenience to the consumer. These provisions might lead to inefficiency. If the buyer is not able to force the seller to repair the product within a reasonable time, ${ }^{44}$ the debtor does not get sufficient incentives to perform since (s)he is not confronted with the sanction of expectation damages.

The last available remedy is rescission of the contract, except in cases where the lack of conformity is minor. In the legal literature, rescission is often regarded as a drastic remedy. This is understandable from the ex ante viewpoint. In that situation, both parties still wanted the contract to be executed. However, in the new situation that has arisen with the non conformity of the product, rescission is not necessarily the most drastic remedy. It might be much more problematic for the debtor to fulfill his original obligations than to reimburse the creditor the payments he already made. In essence, rescission boils down to the payment of restitution damages, which are lower than expectation damages. Therefore, the possibility of rescission might actually lead to under-performance because it is cheaper for the debtor to bring the creditor back in the position (s)he had before the contract was closed (restitution damages) than to restore him or her in the position which (s)he would have reached if the debtor had performed (expectation damages). Obviously, in as far as it is the creditor who is allowed to choose the remedy, this problem will not materialize because the creditor will not opt for rescission if this leads to problematic under-compensation. Since the remedy of rescission is available only if the other remedies are not effective, the possibilities of opportunistic behaviour (i.e. rescind when the needs or preferences of the contract partners have changed since the closing of the contract) are limited. ${ }^{45}$ Priest elaborates upon the costs that would be incurred if the court awarded damages to the buyer as compared to the costs of rescission. ${ }^{46}$ With damages, the court would have to calculate the buyer's loss

\footnotetext{
${ }^{43}$ M. Torsello, 'Substantive and Jurisdictional Aspects of International Contract Remedies: A Comment on Avery Katz's "Remedies for Breach of Contract Under the CISG", (25) International Review of Law and Economics 2005, p. 407.

${ }^{44}$ For example, in the Netherlands the creditor has several legal options to force the debtor to perform. For the purpose of the current paper, the possibility to have the product repaired by someone else and to have the debtor pay for it is the most relevant. Furthermore, the debtor can be induced to perform by the use of civil judicial penalty payments.

${ }^{45}$ Parisi 2004, p. 421.

46 G.L. Priest, 'Breach and Remedy for the Tender of Nonconforming Goods Under the Uniform Commercial Code: An Economic Approach', (91) Harvard Law Review 1978, p. 963 ff.
} 
resulting from the defect, where the parties involved run the risk of over- or undercompensation. Furthermore, the buyer (who keeps the defective product) has to adapt the product or dispose of it. Priest includes also the subjective costs of continued use of the non conform product (i.e. accepting that the product does not have all the characteristics the buyer expected). With rescission, the costs include the costs of returning the product to the seller, the costs of reselling the defective good and the buyer's costs of buying a substitute. Priest argues that the parties would agree to rescission if the sum of the costs of returning the goods is less than the amount of damages. It depends on many circumstances what the efficient remedy would be, especially if also the distribution of costs over the parties involved is incorporated. After all, this opens the possibility that a party would choose the non-efficient remedy because that is better for his or her private welfare. Rational parties would agree upon remedies that are more flexible than the mere choice between rescission and damages. This also includes possibilities of repair and price reduction. However, given the existence of uncertainties (e.g., price fluctuations) and the difficulties to estimate them, it is "difficult to determine the most efficient remedy". 47

\section{Allocation of liability within the contractual chain}

\section{Direct claims}

The economic goal of liability rules is giving incentives to take efficient care to the parties who influence the size of the expected loss. In as far as the non conformity of the products sold is caused by the manufacturer, (s)he should ultimately be confronted with the negative consequences thereof. A direct action can help in this respect, because it enables the buyer to directly claim compensation from the manufacturer, so that (s)he is forced to internalize the negative externalities of selling defective products. A clear advantage of a direct action over the alternative of a multitude of individual proceedings, which obliges each party in the contractual chain to take recourse on its upstream contracting partner, is the savings on administrative costs. ${ }^{48}$ Besides this cost argument, a direct action may be needed to make sure that the producer is effectively confronted with the sanction of liability. As the English report in this volume illustrates, contractual exonerations as well as legal hurdles may seriously hinder the financial incentives of contract parties to travel through the contractual chain up to the producer. Admittedly, to solve such problems, it might make more sense to change the law with respect to the seller's right of redress. One should realize, however, that the EU has no power to harmonize rules not relating to consumer protection (see also section D). A third argument in favour of a direct action is that such arrangement protects the consumer against the bankruptcy of the retailer. This is primarily a justice argument focusing on compensation of the consumer, rather than an efficiency argument focusing on incentives for the producer. However, if the consumer can act only against the retailer, bankruptcy of the latter would effectively bar any claim reaching the producer. The possibility of a direct action avoids under-deterrence by ensuring that the manufacturer still retains

\footnotetext{
${ }^{47}$ Priest 1978, p. 968.

${ }^{48}$ This argument is also mentioned by G. De Geest, Economische analyse van het contracten- en quasicontractenrecht, Antwerp: MAKLU 1994, p. 366.
} 
incentives to deliver goods in conformity with the contract in cases the retailers might go bankrupt.

Besides these advantages, direct actions also suffer from shortcomings. First, it may be doubted whether consumers would actually initiate such a direct action. If the costs of starting such a claim outweigh the expected benefits, consumers may remain rationally apathetic. It is one thing to return the good to the seller and complain about the non conformity. It is quite another thing to directly contact the producer, who may be located in another country and not as close-by as the retailer, in order to get the problem solved. ${ }^{49}$ This problem of rational apathy might be tackled by allowing collective actions or representative actions brought by consumer associations, but these enforcement schemes create problems of their own. ${ }^{50}$ Second, if a direct action is introduced by mandatory European rules, manufacturers lose the option to voluntarily offer the possibility of direct claims, which could serve as a signal of quality and improve market transparency. ${ }^{51}$ The gravity of this problem depends i.a. on the availability of other options to signal quality, such as the price of the warranty and the after sales services offered by the manufacturer (e.g. picking up and returning the product to the consumer's house in case of repair). Third, if the problem of non conformity was not caused by the manufacturer but by careless behaviour of a wholesaler or retailer, the direct action misaligns the incentives to take care. Finally, it may be more difficult for a manufacturer to control or detect the possible risk of consumer moral hazard than it is for the retailer. The latter party had personal contact with the consumer and had the opportunity to provide personalized information regarding the proper use of the product.

\section{Contractual liability of the entire distribution chain (network liability)}

If consumers could bring their claim against any of the parties in the contractual chain (manufacturer- importers/wholesalers- retailers) they would have more possibilities to effectuate their remedies. Network liability enables the consumer to choose the most convenient or most solvent party or the actor who enjoys the best reputation. How should we evaluate such a system from an economic point of view? If network liability increases the chances that the actor who is ultimately responsible for the non conformity is facing a larger probability of being confronted with the negative consequences thereof, the incentives to deliver goods of good quality will be positively influenced. This goal can be achieved in two different ways: i) recourse claims, and ii) a system of vicarious liability. Below, each of these scenarios is further elaborated upon.

An example may illustrate how recourse claims may improve the incentives to deliver goods that are in conformity with the contract. If the retailer went bankrupt and the manufacturer is located in another country so that it is too costly for the consumer to effectuate a direct action, bringing a claim against the domestic wholesaler may be feasible for the consumer. If the wholesaler subsequently turns to the producer in a

\footnotetext{
${ }^{49}$ See also the contribution by D. Standop and G. Grunwald (section C.II) in this Volume.

${ }^{50}$ See e.g. R.J. Van den Bergh and L.T. Visscher, 'The Preventive Function of Collective Actions for Damages in Consumer Law', (1) Erasmus Law Review 2008, p. 5-30.

${ }^{51}$ See also the contribution by D. Standop and G. Grunwald (section D) in this Volume.
} 
recourse claim, the incentives to deliver goods that are in conformity with the contract of sale will ultimately reach the manufacturer. Given that in many instances non conformity is caused by the producer, this is a positive result. However, the costs of the recourse claims should not outweigh the benefits of the improved incentives. Besides the increase in administrative and litigation costs, it must be avoided that an actor in the distribution chain who was not responsible for the non conformity ultimately bears the liability because (s)he cannot take recourse on the responsible party. This may happen due to a contractual exoneration, which provides the liable actor with excessive incentives to take care if this lowers the probability of non conformity. This actor, in effect, could try to mitigate the insufficient care level of the responsible actor, who is not reached through the network liability. However, Parisi argues that the parties in the distribution chain are all repeat players, so that they may incorporate possible liability for non conformity into their contractual arrangements, which would lead to an optimal internal allocation of this risk. Furthermore, upstream suppliers will have incentives to select solvent retailers and to monitor them on their responsiveness towards the consumer, to avoid liability themselves. $^{52}$

Network liability can be understood also as a form of vicarious liability. This type of liability gives incentives to parties upward in the contractual chain to control the behaviour of parties active at lower levels of distribution. On the positive side, this may be economically desirable if the former have possibilities to reduce the risk of non conformity by controlling the behaviour of the latter. The economic optimality of vicarious liability depends on the characteristics of the case. First, the liable party must have possibilities to influence the behaviour of the party causing the loss that are different from the incentives provided by the buyer of the defective product. Hence, if the consumer may easily effectuate his or her remedies against the original seller, thereby providing adequate incentives, vicarious liability does not have an added value but causes only additional administrative costs. Second, vicarious liability is desirable in situations where the seller is not solvent and the producer has non-monetary incentives available to influence the behaviour of the seller. Third, if the producer has better information regarding the product characteristics, vicarious liability for non conformity can provide incentives to instruct the seller regarding the information (s)he should or should not convey to the consumer. Fourth, if retailers are more risk averse than producers, vicarious liability leads to a better risk distribution. This argument, however, is of limited value in a contractual setting, given the possibilities to distribute risks in the contractual chain. On the negative side, network liability creates monitoring costs that could outweigh the advantages in terms of deterrence.

In the English report in this Volume, an interesting version of network liability is introduced. According to this proposal the consumer can not only sue his or her seller or the manufacturer, but any seller who distributes the product. ${ }^{53}$ Under the assumptions that the manufacturer is responsible for the non conformity and that the seller against whom

\footnotetext{
${ }^{52}$ Parisi 2004, p. 422, 423.

53 R.Bradgate and C.Twigg-Flesner, 'Expanding the Boundaries of Liability for Quality Defects', (25) Journal of Consumer Policy 2002, p. 367.
} 
the consumer enforces his or her rights is subsequently indemnified by the producer, ${ }^{54}$ this proposal makes economic sense. After all, the fact that the consumer can choose the most convenient authorized seller limits the problem of rational apathy (i.e. the negative individual benefit-cost ratio of bringing a claim). The assumption that this seller is indemnified by the producer ensures that the incentives ultimately reach the manufacturer. However, the proposal causes administrative costs which may outweigh the benefits. In addition, in cases where not the producer but the original seller caused the problem, the former has to pursue the latter, causing additional costs. This will for instance be the case if the non conformity is caused by the fact that statements of the original seller created expectations from the buyer which were not satisfied by the product. Network liability for such cases of non conformity may induce the manufacturer to better instruct and monitor his authorized sellers, possibly even eliminating them from his distribution channel if they fail to meet quality requirements.

\section{Must consumer sales law be harmonized?}

There is a vast body of Law and Economics literature on benefits and costs of harmonization of laws. On the one hand, divergent legal rules generate several benefits. Competition between legal rules allows satisfying a greater number of heterogeneous preferences and enables learning processes. On the other hand, competition between legal rules may cause inter-jurisdictional externalities or prisoners' dilemmas between states, which create a 'race to the bottom'. Also the existence of economies of scale and the reduction of information and transaction costs may plead in favour of harmonization. Besides the above arguments, which are based on the economic theories of federalism and regulatory competition, further arguments can be derived from Public Choice theory. This approach holds that a central regulator may be better placed to enact welfare enhancing regulation than decision-makers at lower levels who are exposed to lobbying by powerful interest groups. Below, we first provide a short summary of the main economic arguments ${ }^{55}$ and then apply these insights to EC Directive 1999/44.

I. Regulatory competition or harmonization of consumer laws: benefits and costs

\section{Arguments favouring regulatory competition}

The starting point in the theory of regulatory competition is that twenty-seven competing national legislators are better than a single European legislator enjoying a monopoly in the market for consumer laws. Lack of competition in markets for legislation may cause inefficiencies similar to those in non-competitive ordinary goods markets. A monopolistic legislator may reduce output, so that fewer preferences concerning the contents of legal rules will be satisfied. If EC consumer law provided only default rules

\footnotetext{
${ }^{54}$ These assumptions are made by the authors of the proposal, see Bradgate and Twigg-Flesner 2002, p. $367,368$.

${ }^{55}$ For a more elaborate discussion, see R. Van den Bergh, 'The Difficult Case for Harmonising Consumer Law', in: K.Heine and W. Kerber, Zentralität und Dezentralität von Regulierung in Europa, Stuttgart: Lucius \& Lucius 2007, p. 183-206.
} 
(from which parties may deviate in their contracts) or was offered only as an additional (twenty-eighth) choice, the European legislator would facilitate the satisfaction of different consumer preferences across Member States, rather than impede a desirable degree of diversity. The main tasks of the European legislator would then consist of supplying information regarding the different legal systems and allowing parties to freely choose the applicable law. The Draft Common Frame of Reference ${ }^{56}$ contains provisions on conformity and warranties and can be regarded as such a source of information, which better enables parties to choose the legal rule that suits their interests best. However, the great bulk of EC consumer law consists of mandatory substantive rules.

The 'quiet life' of the ordinary monopolist finds its counterpart in the monopolistic legislator's reduced incentives to innovate. By contrast, experimentation and innovation are essential features of learning processes generated by regulatory competition. The theoretical background of this argument can be traced back to the reasoning of Nobel Prize laureate Friedrich von Hayek about the fundamental limitations of human knowledge. ${ }^{57}$ It cannot be assumed that law makers know the best legal rules in advance. The knowledge about the most appropriate remedies for solving new or even well-known problems of market failure (such as information asymmetries in consumer markets) is still limited. The quality of the performance of legal rules and systems of enforcement in a given jurisdiction is revealed by comparing it with the performance of different legal rules and systems of enforcement in other jurisdictions. The Hayekian concept is closely linked to the idea of 'yardstick competition', implying that information about the quality of the performance of governments and enforcement agencies is revealed by comparing it with the performance of others. Politicians may thus be given incentives to copy superior solutions adopted in other jurisdictions. Regulatory competition will be strongest if there is free choice of law. Under the latter scheme, consumers may fully profit from trial-anderror processes and will simply choose the laws that are best adapted to their preferences. $^{58}$

\section{Arguments favouring harmonization}

Whereas there are strong reasons to support competition between rules of consumer protection (satisfying heterogeneous preferences, adaptability to national/regional circumstances and enabling learning effects), the arguments in favour of harmonizing consumer law are weak. A first argument relates to the need of internalizing negative externalities across jurisdictions. From an economic point of view, EC Member States should be able to choose the rules which best satisfy the preferences of their citizens as long as they also bear the full costs of their decisions. Where trans-boundary effects

56 C. Von Bar, E. Clive and H. Schulte-Nölke (eds), Draft Common Frame of Reference (DCFR), Principles, Definitions and Model Rules of European Private Law, Interim Outline Edition, Munich: Sellier European Law Publishers 2008, p. $199 \mathrm{ff}$ and p. $204 \mathrm{ff}$.

57 F.A. Hayek, 'Competition as a Discovery Procedure', in: F.A. Hayek, New Studies in Philosophy, Politics, Economics and History of Ideas, Chicago: The University of Chicago Press 1978, p. $66 \mathrm{ff}$.

${ }^{58}$ Unfortunately, free choice of law is not guaranteed for purely domestic transactions, see G. Wagner, 'The Economics of Harmonization: The Case of Contract Law', (39) Common Market Law Review 2002, p. 1009, 1010. Here still lies an important task for European law, which could change the applicable rules on conflict of laws, in order to improve competition between legal systems. 
occur, central rule making may be required to avoid that costs are thrown upon other jurisdictions. However, national consumer laws mostly do not create significant interstate externalities and, even if substantial cross-border effects occur, national consumer laws may cope with the externality problem. For example, a firm producing in a country with a low level of consumer protection which exports to a country with a higher level of consumer protection will be subjected to the stricter legal rules of the importing state. ${ }^{59}$ Hence, national consumer law can deal with the issues of negative externalities, if any.

A second argument favouring centralization of decision making and (minimum) harmonization is the risk of the 'race to the bottom'. Also this argument does not seem convincing. In the field of consumer law it seems highly doubtful that EC member states will strive for low levels of consumer protection to attract industry. Even in areas of law where one might expect a substantial impact of the desire to attract businesses on the choice of the regulatory burden for industry, theoretical and empirical research show that there is no convincing proof for a 'race to the bottom' and that, by contrast, a 'race to the top' may take place. ${ }^{60}$ It seems even more unlikely that firms will relocate plants to profit from lenient consumer laws. Member states cannot easily gain a competitive advantage by enacting lenient consumer laws, which in any case will not protect domestic firms from claims in export markets. More generally, it is doubtful whether states will engage in a race to the bottom if they cannot charge industry for using lenient rules of consumer law. At this point, a comparison with the alleged race to the bottom in American corporate law is illuminating; one must not forget that 16 percent of the total tax revenue of Delaware is derived from incorporation fees. ${ }^{61}$ Finally, the race to the bottom argument supposes that firms, which have to comply with stricter rules, suffer a competitive disadvantage. However, if rules of contract law are efficiency motivated (rather than based on distributional considerations) they will increase and not decrease the competitiveness of firms. ${ }^{62}$ In the latter case, the race will be for the 'top' rather than for the 'bottom'.

Third, scale economies in the production of legal rules and transaction costs savings could justify harmonization. Scale economies arise if it is cheaper to have legal rules produced by a single (international) legislator, because the information required is not only relevant at the national level, but also at the international level. Such scale economies are especially relevant in the domain of public law, e.g. safety regulation.

\footnotetext{
${ }^{59}$ The picture is different if the country of origin principle (or 'mutual recognition') applies. However, this principle is not a stable conflict of law rule. See W. Kerber and R. Van den Bergh, 'Mutual Recognition Revisited: Misunderstandings, Inconsistencies and a Suggested Re-interpretation', (61) Kyklos 2008, p. 447-467.

${ }^{60}$ For example, there is no support for the claim of a race to the bottom in environmental law (or the 'pollution haven' hypothesis), neither theoretically nor empirically, see M.G. Faure, 'How Law and Economics May Contribute to the Harmonisation of Tort Law in Europe', in: R. Zimmermann (ed), Grundstrukturen des Europäischen Deliksrechts, Baden-Baden: Nomos 2003, p. 47-49 with further references. Firms will not relocate plants to escape from stringent environmental regulations. Other factors, such as the availability of a good infrastructure, labour conditions (unionization of the labour force) and taxes may be much more important in location decisions of businesses.

${ }^{61}$ R. Romano, The Genius of Corporate Law, Washington: AEI Press 1993, p 8-9.

${ }^{62}$ R.J. Van den Bergh, 'Subsidiarity as an Economic Demarcation Principle and the Emergence of European Private Law', (5) Maastricht Journal of European and Comparative Law 1998, p. 137-139.
} 
However, in the field of consumer law they seem negligible. Regarding the transaction costs savings, harmonization does not bring about the legal certainty so much desired by legal commentators. After all, harmonized law only yields legal certainty if the rules are interpreted and applied in a similar fashion throughout the European Union. This already causes problems at the stage where concepts in Directives have to be translated into the different legal systems. Furthermore, harmonization could even increase transaction costs, at least in the short run. New provisions have to be integrated into the national legal orders and this causes adaptation costs. These costs can be very high, especially if the harmonized law is also applicable to domestic transactions. Also, there is no empirical evidence that diverging laws impede cross-border trade. Consumers will not necessarily increase cross-border shopping if consumer laws are made uniform.

Finally, one could argue in favour of EC intervention to cure potential deficiencies of national law. European law could accomplish a useful task if the rules of the import country do not allow a full internalization of externalities or do not correct market failures in an effective way. The task of the European legislator would then be to fill the gaps of national laws if, for some reason, national legislators cannot organize a watertight consumer protection. This line of reasoning points at inefficiencies in national laws and thus argues in favour of central rule making by stating that laws enacted by a central regulator are more efficient than laws enacted at lower levels of government. However, the view that EC consumer law is more efficient than national consumer laws is not generally supported by real-life harmonization. ${ }^{63}$

\section{EC Directive 1999/44}

The Consumer Sales Directive is one of many examples that confirm the general insight that economic arguments in favour of harmonizing consumer protection laws are weak. Member states may have different preferences regarding diverse policy options; they may either wish to improve information flows or prefer mandatory rules for protecting 'weak' consumers. Also learning processes remain very important and should be kept intact, as the above discussion on optimal remedies (see C.II) illustrates. Generally, it would be wise for the European legislator to enact default rules that may be instrumental in looking for the economically optimal solution of complex problems.

The most powerful economic argument in favour of harmonization is the need of coping with interstate externalities. From this perspective, the Consumer Sales Directive is both over-inclusive and under-inclusive. In this Directive the externalities problem is not a major concern of the European legislator. On the one hand, the Directive applies to purely domestic contracts, which do not generate any cross-border externalities. On the other hand, the important matter of upstream liability is curiously left out of the harmonization project. ${ }^{64}$ There is no rule to avoid that claims in cases of non conformity with the contract terms stop at the border. A consumer can sue a retailer, who could exercise his right of redress against a wholesaler or the importer, but the availability of a right of redress against the producer in an export country is left to the national law of that

\footnotetext{
${ }^{63}$ For examples, see R. Van den Bergh, 1998, p. 140-145.

${ }^{64}$ See consideration 9 of Directive 1999/44, cited footnote 1.
} 
country. Given the interstate externalities that an absence of upstream liability may cause, it is remarkable that the Directive does not regulate this issue. Other arguments that might support harmonization, such as the risk of a 'race to the bottom' and transaction cost savings have been critically discussed above. These arguments also apply fully in the case of the Consumer Sales Directive.

\section{E. Conclusions}

Traders may sell goods that do not meet consumers' expectations. Economic analysis of law provides an explanation as to why goods of inferior quality may be sold and suggests legal remedies to overcome this deficiency. Warranties in this respect have several functions: they contribute to better risk spreading between sellers and buyers, they improve information flows in consumer markets and they provide incentives to perform the contract. Given these different economic functions, the optimal warranty varies according to the risk attitudes of sellers and buyers, the availability of information in markets and the possibility of either sellers and/or buyers to control the risk of non conformity.

It seems clear that the drafters of EC Directive 1999/44 did not have the economic functions of warranties in mind when they laid down the requirement of conformity. Even though the Directive deals with commercial warranties separately, the duty to deliver goods that are in conformity with the contract and the two year limitation period for bringing claims for non conformity generate economic effects that are similar to those of a statutory warranty. This may generate inefficiencies. Due to the mandatory character of the Directive, sellers are no longer able to offer commercial warranties that exclude liability for non conformity within two years from the date of sale, even though buyers may wish to trade lower quality for a lower price. Besides the risk that fewer preferences may be satisfied, the Directive may be criticized also from the perspective of the signaling function of warranties. The European legislator missed the opportunity to improve market transparency by requiring a separate indication of the full price of the product (including costs of expected claims) and the price of the warranty (including its insurance function). In addition, fixed limitation periods generate inefficiencies since their optimal duration depends on a number of factors that vary across different consumer sales contracts.

Economic analysis is also useful for assessing the efficiency of the remedies provided by the Directive. A general insight from Law and Economics is that performance of the contract is only desirable as long as the costs of performance do not outweigh its benefits. Expectation damages provide incentives for efficient breach. However, if damages are not assessed correctly (such as in the case of unique goods), specific performance may be the preferred remedy. The duty to repair resembles specific performance. By excluding this remedy when it is disproportionate, the Directive allows efficient outcomes provided the proportionality criterion is assessed by a comparison of the costs of repair to the seller and the value increase to the buyer. If replacement allows the debtor to offer a substitute good, the result comes close to the economic criterion that damages equaling the price of 
a substitute good are an efficient remedy in the case of replaceable goods. The order of remedies, which obliges the creditor to first ask repair or replacement before a price reduction or rescission also makes economic sense. It avoids over-compensation and opportunistic rescission of the contract (because the buyer regrets the purchase). As a remedy, price reduction seems problematic since it may not compensate the buyer for the loss in value due to non conformity and cause under-deterrence. Rescission may equally lead to under-performance since restitution damages are lower than expectation damages.

The conclusion of the section on allocation of liability within the contractual chain is that both a direct action and network liability have the potential to improve the incentives received by the manufacturer. If (s)he is indeed the party responsible for the non conformity, this is a positive achievement. However, these benefits should be weighed against the increase in administrative costs caused by recourse claims within the contractual chain. In cases where the incentive structure is not improved, e.g. because liability ultimately falls with a party who was not responsible for the non conformity, the evaluation turns out negative. After all, the increase in administrative costs is not made good by improved incentives.

Finally, the paper has shown that economic arguments favouring harmonization of consumer sales law are weak. Preferences concerning levels of consumer protection vary across EU Member States and different rules remain necessary to enable learning processes. A risk to the bottom is unlikely and the suggested transaction cost savings are not substantiated by empirical evidence. Internalization of inter-jurisdictional externalities, which cannot be overcome by national laws, could potentially justify regulatory action at the European level but, remarkably, the Consumer Sales Directive does not deal with this issue. 